\title{
Comparing French Borrowed Words in English and Those in Vietnamese
}

\author{
Phuong, Vo Tu \\ Khanh Hoa University \\ Corresponding author. Email: votuphuong@ukh.edu.vn
}

\begin{abstract}
Borrowed word is the product of a process of language development and cultural exposure. French borrowed words appear quite a lot in English and in Vietnamese. In this article, I will briefly study and compare French borrowed words in both English and Vietnamese vocabulary. In the first part, the article studies the history of French borrowed words in Vietnamese and in English, and in the latter sections, I will focus on studying borrowed word forms on the basis of dictionary research. Then, this article points out the importance of borrowed word learning for EFL (English as a Foreign Language) learners, especially Vietnamese ones, and gives some tips for learning borrowed words.
\end{abstract}

Keywords: borrowed words, French borrowed words, meaning, EFL

\section{INTRODUCTION}

A language is an important tool for human communication, it reflects the development of society, and it also undergoes changes throughout history. Languages are like cultures because they are rarely sufficient for themselves because the necessity of communication causes speakers of a language to communicate directly or indirectly with neighboring languages of dominant languages.

Therefore, the result of constant contact between different words and phrases, then people use each other's words to refer to the same thing, the same process of formation, or the same thought. The use of other languages is called "borrowing." This is a natural result of language contact and has profound effects on both lexical enrichment and mutual cultural understanding.

Borrowing can be direct between two languages contacting. Many linguists have attached importance to this process and the study of loanwords (e.g., words created in the process of borrowing) in languages, where a few words related to loanwords, they then do further research on the subject and offer advice for learning loanwords.

This study involves French loanwords in English and Vietnamese, thereby comparing the areas of French loanwords in these two languages.

English is currently considered an international language and is the second language of many countries in the world; even it is the administrative language of some countries such as Singapore, India, Malaysia, Philippines, which can clearly confirm the position of English in the world. Over thousands of years of development, many changes in the process of historical formation have made English change, become richer, or it can be said to be gradually improved. And so far, it itself has not stopped growing. To prove this, we can see that many words, phrases, idioms, etc., have been born in order to better serve the communication, expression of ideas and economic and social development, and science. It won't be a surprise if you overhear a British person saying a few words that you think are definitely the language of your country. That's the borrowed word. Like any other language, English consists of two parts: native English and borrowed 
English. It is surprising that the number of borrowed words in English is much larger than the original words. Indigenous words make up only $30 \%$ of the total number of words in English, but they are the foundation to form most of the familiar words frequently used in the spoken and written language. Borrowed words are words that are derived from another language and words that have been modified to suit the characteristics of native English. In fact, due to a long period of formation and development, it is difficult to distinguish a borrowed English word from a native word without a thorough analysis of its origin and history. It is the stages of development of a formal language that determine the number of loanwords as well as their role in the world system of a language.

Regarding the word borrowing in English, there have been a number of studies on the phenomenon of borrowing words in English, such as in the article "The history of loan words in English and its impact on the English Lexicon" by Jumah Yousif Qreshat published in the Journal of Critical Reviews in 2019 (Jumah, 2019 [47]) discussed the evolution of English vocabulary due to borrowing. The article has studied this problem in two parts: about the meaning and the formation of the word. The article is also about the long-term effects of borrowed words on the formation of vocabulary in English.

A special study about this issue in the book "Borrowed Words: A History of Loanwords in English" by Philip Durkin (2014) [35] which clearly covers the history of loanwords in English from different periods of time from the very beginning up till now. it assesses the profound variation in all classes of English words that are the result of integrating vocabulary from different sources.

Borrowed words in Vietnamese. Vietnam has experienced more than a thousand years of Chinese domination and nearly 100 years of being invaded by the French, so it is more or less affected by the culture and languages of these countries. Besides, the introduction of different cultures into
Vietnam makes cultural values change drastically and also contributes to enriching Vietnamese vocabulary.

Regarding the problem of borrowed words in Vietnamese, there have been works "The basics of linguistics and Vietnamese" ("Cơ sở ngôn ngũ học và tiếng Việt’') by Mai Ngoc Chu, Vu Duc Nghieu, Hoang Trong Phien (2008) [28], studied the basic issues of languages, including the problem of loanwords in Vietnamese. The work "Understanding national cultural characteristics of language and cognition in Vietnamese people" (in comparison with other ethnic groups)" ("Tìm hiểu đặc trung văn hóa dân tộc của ngôn ngũu và tu duy ở người Việt (trong sụ so sánh với các dân tộc khác”) by Nguyen Duc Ton (2002) [29], presented and explained cultural characteristics. Ethnicity of language and thinking when approaching language from the perspective of different cultures. However, the author of the book only restricts the comparative study of the national cultural characteristics of language and thinking, mainly in Vietnamese and Russian people, so the comparison of language and thinking is just in a few areas, which is very limited. Author Nguyen Thien Giap (1998), in the book "Introduction to Linguistics"

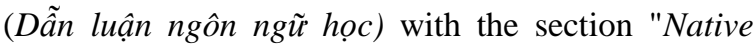
words and foreign words" discussed the factors to distinguish native words from foreign words, which are: old elements, those from the previous period; new elements, imported from other languages during that period; New products are built on the basis of old elements and newly introduced elements. Author Phan Thi P.T. Tinh [39] has researched "Assimilation of French words in Vietnamese" (Sụ đồng hoá các tù gốc Pháp trong tiếng Việt) has studied French words in Vietnamese, and the problem of Vietnameseizing these words.

Some of its changes are inherent to all languages, while others are the product of linguistic interaction. Foreign influences on English are so strong that they have transformed the language from a near-pure form to a wholly mixed one. French is the language that has had the most effect on English. According to a computerized assessment of around 80,000 terms in the Third Edition of the Oxford 
Dictionary released in 1973 by Thomas Finkenstaedt and Dieter Wolff [45] in the journal Ordered Profusion (1973), it is estimated that the origins of the English words from French is $28.30 \%$

Better understanding the origin of French loan words in English and Vietnamese, thereby helping to find out how to learn English vocabulary more effectively. This has important implications for foreign language learners, especially students majoring in English.

\subsection{Borrowed words}

Currently, in the world, there are many languages being used for communication, cultural exchange, business, educational development. Each language has lexical features expressed in lexicons with hundreds of thousands of words. Speakers of this language come into contact with speakers of other languages for different reasons. Therefore, when languages come into contact with each other, there are forms of translation from one language to another, which are called "borrowed words" or "loan words."

A language to express an idea that is not present in that language but is available in another language often borrows words. "Borrowed words" or "loan words" are words borrowed from a foreign language to enrich the vocabulary of the recipient language. Nearly all languages in the world have loanwords, and English and Vietnamese are no exception. The purpose of borrowing this word is to convey ideas because a language inherently does not have enough vocabulary to define all concepts and lexical translation from one language to another. Borrowed words have an indispensable position in the integration process of a country or a culture. Borrowed words appear in a language when the word is used by many speakers of that language and carries a certain meaning. English and Vietnamese are no exception to this rule. There are loan words from French, Latin, Chinese, and many other languages in both English and Vietnamese. However, in each language, the number of words borrowed from different sources is different for different reasons and the fields of borrowing.

\subsection{Definition of a borrowed word}

Borrowed words are those that are used by speakers of one language from speakers of another language. Borrowing is often metaphorical in nature due to the non-literal nature of the procedure. The terms are simply employed by a group distinct from the one from which this language evolved. Borrowing may occur as a consequence of cross-cultural interaction between two language populations. In this situation, the language community has certain benefits in terms of power, reputation, and scientific and technological richness, which makes the idea's objects appealing and other communities desire to adopt the language. For example, when the Vietnamese were invaded by the French in the 19th century, they used many words borrowed from French when they received the French's cultural and technological knowledge. However, there are very few Vietnamese words used in French.

The actual borrowing process is complex, involving many events and many instances in which the word borrowed is used. Borrowers accept the new word because it best fits the idea they are trying to express, they may pronounce the words the same or similar to the pronunciation in the source language, or they use the meaning which can be the same or almost the same as that in the source language, for example, the Vietnamese people when using the French word "pedal," converted it into the word "pêđan" in Vietnamese.

The early adopters of borrowed words probably only used it to communicate with those who spoke the source language. However, at some point, they use this word with people in their cultural community, and gradually these borrowed words become the vocabulary of the other cultural community. Later, it is no longer considered a foreign word but has become part of the vocabulary of that borrowed language. For example, the French word "lavabo" (washbasin) has been Vietnameseized into the word "lava-bô," or other words such as baguette (bánh mì ba-gếch," le gare (nhà ga), etc. have been victimized into common words, common vocabulary. 
However, many individuals get used to unfamiliar foreign forums over time. A term that progressively penetrates an ever-larger community and becomes a part of that community's linguistic repertoire via the use of borrowed language sounds and characteristics when speakers unfamiliar with the source language adapt it to their language system. Synonyms are those in which the longer a loanword has been in a language, and the more often it is used, the more similar it is to the language's original word.

Borrowing is a socialization process that not all members of the linguistic community recognize. In certain nations, the language is kept "clean," and loanwords are considered "forbidden." For instance, in France, they attempted to prohibit the use of English terminology in French by legislation.

\section{FRENCH BORROWED WORDS IN ENGLISH}

Every language borrows terms from another. During the period after the Norman Conquest in 1066, English absorbed an enormous quantity of terminology from French. The conquest facilitated the introduction of the words "court," "law," and "property" into English from French.

French loanwords in English date all the way back to Norman French, while subsequent loanwords derive from Middle French. The winners' terms appear in several areas of the English language: administration "administration" (for example, government "government"), military (for example, captain "captain"), religion "religion" (for example, abbey "monastery"), law "law" (for example, crime "crime"), entertainment "entertainment" (for example, card "card"), arts "arts" (for example, color "color"), and handicrafts "crafts" (for example, butcher "butcher").

English includes several French terms relating to art, sports, money, and diplomacy. The majority are pronounced according to English phonological norms. Generally, a term or phrase preserves its French identity if it retains French accents or is often italicized. Other terms look accurate to English speakers but are unfamiliar to French speakers. This is because a large number of them have ceased to exist or have changed insignificance. Many menus in British and American restaurants are now written in French: exceptional, fromage blanc, amusegueule, mesclun, nouvelle cuisine, aperitifs, pain au chocolat, café au lait, entrée, jambalaya, chowder, and so on. Additional loanwords from politics, sports, fashion, and the arts include bon chic bon genre, chef d'équipe, parkour, soigneur fonctionnaire, franc fort, touché, dossier, déjà vu, vis-à-vis, faux pas, nouveau riche, rentier, jamais vu, elite, ambiance, collage, repertoire, entourage, tranche, toboggan, bete noire, enfant terrible, and others. blanc fromage, amusegueule, mesclun, neoclassical cuisine, aperitifs, au chocolat, café au lait, starters, jambalaya, chowder, etc. Borrowing from politics, athletics, fashion, and art, including parkour, déjà vu, vis-à-vis, faux pas, nouveau riche, and annuitant.

\subsection{Reasons to borrow French words in English}

Numerous variables contribute to the acceptance of a term into a language's lexicon. Durkin recognizes "need and prestige" as the two "conventional" justifications for lexical borrowing, but he also highlights both notions' flaws (2009: 142). Borrowing to meet semantic requirements often happens when the borrowed language lacks a term to convey a fact or when novel notions need vocabulary expression. However, even if it were true that new conceptions were continuously developing in a particular community, claiming that borrowing was essential to bridge the structural gap left by Old English would be an exaggeration.

Middle English, hypothetically, would borrow a large number of terms from French owing to a dearth of vocabulary, since Old English was very hesitant to borrow new words from Latin, preferring to utilize its own sources for translation and semantics (Nielsen 1998: 133) [14]. However, those vernacular resources gradually faded into obscurity alongside the long-established tradition of West-Saxon literature as a result of significant historical and political changes (e.g., the Norman conquest), while religious reforms and social changes in England and throughout Europe 
during the 12th and 13th centuries sparked the need for new modes of expression.

\subsection{History of French borrowing in English}

\subsubsection{History of French borrowing in Old English}

Old English borrowed many words from French. British monks studied in France, where the monastic revival began.

Most notably, there is a strong bond between the two civilizations as a result of Edward the Confessor's exile to Normandy (from 1003 to 1005 1066). Edward spent 25 years there before returning to England in 1041 with French courtiers. When he ascended to the throne, he elevated a number of French nobility. The result is a handful of French loanwords, including capon "castrated cock," serving "serve-serve," bacon "bacon-bacon," jail "prisonhouse," and Castel "castle-castle."

On Christmas Day 1066, William was crowned in Westminster Abbey, and this gesture of victory, which included a ceremony in both French and Latin, signified England's position for the next two hundred years. William is fluent in French and attempted but failed to learn English owing to a lack of study time. French was designated as an intelligence language, whereas Latin was designated as a professional language.

The Norman monarchs typically did not speak English; however, Henry I did have an English bride who spoke a few words of the language. It was trendy for the upper class to speak French. Until recently, the usage of French terms in the speech was seen as a sign of delicacy or skill.

While French has cultural and social importance, Latin continues to be the language of church and education. Native English is a widely spoken language. The fusion of these three traditions may be observed in terms such as "kingly." The Anglo-Saxons had just one term for this notion, which was composed of the letters king - king. Three synonyms entered the English after the Normans: royal - "royal," regal - "royal," and sovereign "supreme."
Why is it that the English language continues to exist at this time period? The first reason is that, prior to Norman's invasion, Old English, both written and spoken native English, had become too entrenched and impossible to eradicate due to their merging with the Scandinavian language. The second reason English exists is that the Normans started marrying the populations they conquered. Thirdly, and maybe most significantly, the Anglo-Normans lost control of their French possessions in the Channel in 1204 .

Numerous members of the Norman aristocracy were compelled to pledge allegiance to either France or England due to their ownership of territories in both nations. The usage of French, on the other hand, is not prohibited. By comparison, French was considered the exclusive language of government records and had largely supplanted Latin in the majority of official papers by 1300. In 1362, Edward III passed a statute mandating oral sessions in court to be conducted in English. Nonetheless, records were kept in Latin, and legislation was drafted in French.

\subsubsection{History of French borrowing in Middle English}

France and Great Britain's socio-historical intersection stands out more than that of any other nation in Europe due to its geographical closeness, centuries of conquests, political and scientific alliances, and trade ties. This is particularly evident in the two languages' lexicon. French, in particular, became the language of the governing elite in England for more than two centuries after the Norman invasion. French loanwords account for approximately $40 \%$ of this period, affecting all semantic fields except for fundamental terms relating to the physical environment (such as wind, rain, sun, earth, etc. ), major body parts (such as the head, arms, legs, and abdomen), and some names of familial relationships (such as mother, father, brother, sister, brother, son, and daughter) (Wise, 1997, 81) [16].

By the early 13th century, the rising prominence of French as an international language of politics and culture secured the language's ongoing usage in Britain. As a consequence, the number of bilinguals 
dramatically rose, as proficiency in French is necessary for a variety of fields, including government, law, education, and literature. Bilingualism was not reserved for the aristocracy but was widely practiced by merchants, attorneys, and secretaries.

When English was eventually reinstated as the official language in territories formerly occupied by the French in the fourteenth and fifteenth centuries, a large amount of French vocabulary was converted to English. Early Modern English (1500-1660) and throughout the 18th century retained a considerable French linguistic element.

\subsubsection{History of French Borrowing in Modern English}

With Britain as an economic and scientific giant in the mid-nineteenth century, a great deal of English was absorbed by the French in areas like textiles, fashion, sports, industry, commerce, science and technology, and entertainment. Among the English loanwords are jersey-"shirt", cardigan"corset", blazer-"sweater", weekend-"weekend", lobby-"lobby", jazz-"jazz", film-"movies", star-"star", pullover-"t-shirt", pajamas-"pajamas", boycotter"boycott", gadget-"gadget", and so on. The flood of English loanwords got a new momentum in the 1930s and particularly after Global War II when the United States assumed economic and military dominance on the world stage. According to Wise (1997), the rise of mass media connects with the growth and expansion of the United States, resulting in the marketing of American goods, ideas, and lifestyles. This is reflected in loan words such as snack bar-"mini pub", hotdog-"hotdog", hamburger-"meatball", bestseller"bestseller", chips-"potatoes" french fries", blue jean-"jeans", sweater-"sweater", flash-back"flashback", marketing-"marketing", joking"joking", fan-"fan", gag- "closing", tee-shirt-"t-shirt, etc.

In the 20th century, words were still borrowed from France, although in the 19th century, the degrees of naturalization, anglicization, and massification of words varied widely. Even some recent loanwords are of interest, while other loanwords are often technical in nature with limited use. They now appear most frequently in the vocabulary of art, literature, theater (e.g. revue"modification", vers libre-"compare”, montage“edit"), costume (georgette-"joocjet", marocain"silk fabric", rayon-"artificial silk", etc.), and in mechanical, especially engine and aviation (fuselage"fuselage"; garage- "garage"; hangar-"hanger"; limousine-"large luxury car with glass separating driver and passenger"; longeron- "fuselage"; nacelle-engine cover aircraft") (Serjeantson 1935, 168).

\subsection{Features of French loanwords}

\subsubsection{Diversity}

French loanwords in English cover a wide range of topics.

The French influence became more apparent in 13thcentury English texts. Around 10,000 French terms were believed to have infiltrated the English language at the period. These terms are often used in domains other than law and administration, such as medical, art, and fashion. When new terms were brought into English, several pieces of evidence indicated that they were derived from Anglo-Saxon words. There are two conceivable consequences in such instances. Either term will eventually supplant another; alternatively, both terms will persist but take on somewhat different meanings. For instance, "beautiful" takes the role of writing, while "place" takes the place of stow. Both terms survive in certain instances: "home" (Old English) and "mansion" (French), or "hearty" (Old English), and "cordial" (French) (French). French loanwords in English come in a wide variety of word forms. Over $70 \%$ of the vocabulary is composed of nouns, the majority of which are abstract concepts formed using new French marks such as con-, trans-, pre-, -ance, -tion, and - ment. Around $75 \%$ of these terms survive in current languages.

\subsubsection{Flexibility}

French loanwords in English can form from substitution. Zero substitution, substitution, and 
partial substitution. These kinds of words are very flexible and different to make the language precise and concise.

For example, the loan words Lunik and parkour are replaced by changes in spelling and pronunciation, other loanwords such as chauffeur (from French), which has no changes in spelling and pronunciation.

The Normans took notes on what they heard from the English and started spelling it according to French traditions, such as qu for $\mathrm{CW}$ (queen for cwen). They substituted gh for $\mathrm{h}$ in terms such as "night" and "plenty," and ch for c in words such as "church." Additionally, they substituted ou for u (as in "home") and began using $\mathrm{c}$ before $\mathrm{e}$ (instead of $\mathrm{s}$ ) in phrases such as circle and cell. $\mathrm{U}$ is substituted for o to make difficult-to-read words like $\mathrm{v}, \mathrm{n}$, and $\mathrm{m}$ simpler to read. English spelling in the early fifteenth century was a hybrid of Old English and French.

Some consonants began to be spelled differently, mainly due to French influence. For example, Old English $s c / \int /$ was replaced by sh or sch (scip became ship-"ship"), although some dialects use $s$, ss, or $x$. New conventions for displaying long and short vowels were born, which marked auxiliary vowel characters such as see (earlier se).

\subsubsection{Assimilation}

When new languages are introduced into any language, there is Assimilation. Language assimilation can be divided into two types: internal assimilation factors and external assimilation factors.

Internal assimilation factors include 1. the absence of equivalent expressions at different levels in the structure of English, 2. pressure from the system, 3. the emergence of some different forms, 4 . new problems in word formation, 5. Differences of similar expressions in the original language.

External assimilation factors include: 1 . the different names of the borrowings in oral and written forms, 2. the sociocultural background at the time when certain elements are borrowed, 3. the sociocultural background of the referrer or later users' sociocultural backgrounds, 4. the British recording system.
English loanwords borrow a large number of foreign aphorisms, slangs and phrases and assimilate them, making English expressive and rich.

For example: jamais vu, daja vu, cherchez la femme, flea market (in french),

Any language's vocabulary is composed of several layers of vocabulary from various sources, resulting from speakers' interaction with other groups at various points in their history. English is no different in this regard, and some of those layers are still apparent or at the very least identifiable in the present English language. In modern English, it is sometimes difficult to define certain words as loanwords due to their eventual compliance with the rules of English morphology, stress, and spelling (Nielsen 1998: 10-11) [14].

\section{FRENCH LOANWORDS IN VIETNAMESE \\ 3.1. History of French loanwords in Vietnamese}

In 80 years of being ruled by French colonial rule, the Vietnamese language has been left a mark of French, including a class of words borrowed from French. French loanwords appearing in Vietnamese bring with them the content of Western culture and civilization through new concepts and technical terms. Over such a long period of time, many French loanwords have been Vietnameseized, including how to read and write.

The French had the plot to invade Vietnam in the early 17th century; they used the pretext of preaching, trading and officially invaded Vietnam in August 1858. The French implemented the policy of Frenchization (Francicer) in Vietnam, including language.

The ruling apparatus in Vietnam during these years had both the French and the Vietnamese, creating a state of French-Vietnamese bilingualism. Most of the officials who hold power to rule from the commune level and above belong to the feudal landlord class who colluded with the French colonialists to act as their henchmen. Thus, with the mixed French-Vietnamese ruling apparatus in which 
the French took the helm, there appeared unequal French-Vietnamese bilingualism in the ruling class, with French being the dominant language $(\mathrm{H})$ and Vietnamese being a low language (L).

It is worth noting that "unlike the situation of using French in other former French colonies, French has never been the language of the whole (or the majority) in Vietnam. However, there was a time when it was used as the official language in official documents, in education in schools. Because, at that time, when the majority of our people were illiterate. Communication with the colonial government was the job of a few." This can be proved through the "stupefy policy" of the French colonialists, so the Vietnamese people at that time "were 95\% illiterate" is not difficult to explain.

\subsection{Forms of French loanwords in} Vietnamese in terms of semantics

\section{a. Borrowed French word the whole word}

Those who are fluent in French will use FrenchVietnamese communication in a standard way. In other words, they borrowed more formal French words

For example:

- Bravo! Petit papa!

- A la Sante de papa?

b. Borrowed French words by phonetic transcription (recorded in quốc ngũu script)

For example:: đốc-tờ (doctor), à-la-xô (à l'assaut), phú la căng (foutre le camp "cuốn xéo"), can-xi-om (calcium), ê-li-om (helium)

c. Borrowed French words by reading SinoVietnamese as an intermediary.

This kind of borrowing is common in proper French names or place names and sometimes in parentheses to add French spellings, usually proper name terms. For example: Tô- cách -lạp (Socrate), Nãi-đoan (Newton), Lê- Liên (Lorraine)

d. For people whose French has not yet reached the level of bilingual Vietnamese- French, or who do not know French, they often use some French elements in communication.

For example: ăng- voa: envoie (gởi), me-sừ di-dăng: monsieur sergent (hạ sĩ quan), Cô Soong: cochon (con lợn), cu- tô: Couteau (con dao), la -cua: la cour (cái sân), la - săm: la chambre (căn phòng), a-mi: ami (bạn thân), Ba tô: bateau (tàu thủy), bông cơ: bon coeur (lòng tốt)

Because of approaching French in many different ways, different Vietnameseization has created many variations for the same French word.

\section{e. Borrowed a part}

French loanwords are used in Vietnamese in the following ways:

1. Borrowed by the Transliteration translation For example: sốt vang (sauce au vin), áp-phe (affaire), xiếc (cirque)

\section{Borrowed by way of translation into Vietnamese}

For example: đường sắt: chemin de fer, Phớt Tỉnh ăng-lê: le flegme d'anglais, từ $\mathrm{A}$ đến $\mathrm{Z}$ : de $\mathrm{A}$ à $\mathrm{Z}$, vũ trang đến tận răng: armmé jusqu au dent

3. Borrowed directly from French, but the origin may come from Latin or English

For example mít tin: meeting, cà phê: coffee, đấm bốc: box, boxer, cao bồi: cowboy

4. Borrowed by using the sound of Sino-Vietnamese (Hán-Việt) for example:

For example: yên sĩ phi lý thuần: inspiration,

Tên địa danh: Phú Lang Sa (France), Lục Xâm Bảo (Luxembourg), Lỗ Mã Ni (Romania),

Tên người: Nã Phá Luân (Napoleon), A Lịch Sơn đại đế (Alexander đại đế), - Bối Đa Phần (nhạc sỹ Beethoven), A Lịch Sơn Đắc Lộ (Alexandre De Rhodes),

5. Borrowed the original writing style, but the pronunciation can be changed

For example: "veste" áo vét, "pardessus": áo pa-đò suýt, "chemise" áo so mi

6. Some French loan words in Vietnamese are formed by reconstructing French words

For example: "pê-nan-ty" (penalty), "ghi-đông" (guidon), “đàn ghi-ta” (guitar), “ca-bi-nê" (cabinet), "nhà ga" (la gare) 


\subsection{Word fields in Vietnamese that have French loanwords}

\section{a. In the cuisine}

For examples: bánh bích quy (biscuits), bò bít tết (steak), ca cao (cacao), cà rốt (carottes), kem (crème), mù tạt (moutarde), ốp la (omelette), phô mai (format), sâm banh (sampan), sô cô la (chocolat), sôt (sauce), vang (vin), xúc xích (saucisse)

\section{b. Trang phục, trang điểm}

For examples: Ma-nơ canh: mannequin (mô hình người mẫu), Vét-tông: veston (trang phục của nam), Bi-ki-ni: Bikini (áo tắm), Voan: voile (một loại vải)

\section{c.Costumes, makeup}

For examples: Ma-nơ canh: mannequin (mô hình người mẫu), Vét-tông: veston (trang phuc của nam), Bi-ki-ni: Bikini (áo tắm), Voan: voile (một loại vải)

\section{d. Measurement}

For examples: Gram: (gramme), Héc-ta: (hectare), Ki-lô-mét: (kilometer), Lit:(littre), Mét: metre, Vôn: volt

\section{e. Construction}

For examples: Ban công (balcon), bê-tông (beton), cốp-pha (coffrange), đi-văng (divan), ki-ốt (kiosque), véc-ni (vernis)

\section{f. Building houses}

For example: Ban công (balcon), bê-tông (beton), cốp-pha (coffrange), đi-văng (divan), ki-ốt (kiosque), véc-ni (vernis)

\section{i. Music, art:}

For example: âm ly (amply), ca-mê-ra (Camera), cát sét (cassette), đăng -xinh (dancing), ô-pê-ra (opera), ghi-ta (guitar), ba lát (ballad), đít-cô-téc (discoteque), pi-a-nô (piano), phim (film)

\section{j. Culinary}

For example: ca-cao (cacao), cà rốt (carotte), sô-đa (soda),

\section{k.Transport, equipment}

For example: bu-gi (bougie), bu-lông (boulon), camnhong (camion), xe buýt (le bus), mô tô (motor), cô tông (cotton)

\section{l. Information}

For example: áp-phích (affiche), ca-nông (canon)

\section{m. Education}

For example: com-pa (compass), phốt (faute), cóp-pi (copier)

\section{n. Medicine}

For example: $a$-xê-tôn (acétone), a-mi-đan (amydal), a-xít (acide), đốc-tò̀ (docteur)

\section{o..Science:}

For example: các-bon (carbon), sun-phát (sulfate). Các-bô-níc (carbonique)

\section{COMPARISON OF FRENCH LOANWORDS IN ENGLISH AND IN VIETNAMESE}

French loanwords in English have a very old age, more than 1000 years, while French words from French loanwords in Vietnamese only appear in Vietnamese for a short time.

French loanwords in English and in Vietnamese have the common features that French loanwords are often in the high position $(\mathrm{H})$, used in aristocracy or in people of high status, then native words are usually in the lower position (L).

French loan words in English account for quite a lot, about $30 \%$ of the vocabulary in English, while French words in Vietnamese account for only a small part. The work of the Max Planck Institute for Anthropology and Evolution (2009) was conducted to find root words and loan words in 1000-2000 core vocabularies of 41 languages in the world, showing that in Vietnamese commonly used words, there are only $28,1 \%$ are loan words of which $25.3 \%$ are Chinese loan words, $1.2 \%$ French loanwords, according to Max Planck (2009), and French words borrowed in Vietnamese are mainly in science which expresses new aspects of life.

In general, French loanwords in English and Vietnamese have a similar history. It is the invasion and domination of the French over the native English and Vietnamese people. However, words borrowed from French in English will create pairs of words with the same meaning but different nuances, while in Vietnamese, there is no such phenomenon, but there are many words with the same expression such 
as đàn duong cầm, đàn Pi-a-nô (piano), đàn vĩ cầm, đàn vi-ô-lông (violin).

French loan words in Vietnamese are words with new concepts that first appeared in Vietnamese, for example, chemical tools or technological devices that first appeared in Vietnamese such as bicycles, cars ... will bring along its parts into the language, for example, car parts. Or when Western dishes appear in Vietnamese, they will also bring along the ingredients and materials used for cooking that dish. Meanwhile, French loanwords in English are words with old concepts. However, French loanwords show a sense of nobility, or only people of the upper class use the French word in English as a form of fashion or as a form of the higher class of the users.

The similarity of loan words in English and Vietnamese is that over time; there are equivalent pairs of words forming parallel pairs of words that exist between the borrowed word and the native word (from Sino-Vietnamese and Vietnamese).

In addition, there are some words that still retain their unique value; that is, there are no Vietnamese words or English words that can be replaced. This phrase exists in both English and Vietnamese. For example, in Vietnamese, the loan words are synonyms: đốc- tờ (Doctor) = bác sĩ, nhà băng (bank) = ngân hàng, khách sạn (hotel), vi-la (Villa) = biệt thự, ô-tô (automobile) $=$ xe hơi chơi ,xà phòng, xà bông (savon)

\section{CONCLUSIONS AND RECOMMENDATIONS}

In short, French loan words in English and Vietnamese have similarities and differences. If loan words in English have a history of more than 1000 years, French loanwords in Vietnamese only have a history of about 100 years, so the loan words and the number of loan words in different fields are different.

French loanwords in English are expressed in the upper and upper classes, while French loanwords in Vietnamese represent each class of educated, knowledgeable, and knowledgeable people.

The loan form of French in English and Vietnamese is slightly different. Vietnamese borrowed from French is expressed in many forms of borrowing such as by way of travel, by direct borrowing, by way of translating into Vietnamese, by using another language such as Chinese, the Latin language. Borrow the spelling, and the reading is very diverse, or borrow but restructure the word.

Meanwhile, French loan words in English usually remain the same or change a little in spelling, and most of them keep the same or keep the same way of reading; most French loan words in English or Direct borrowing is through another language such as Latin. And French loan words in Vietnamese can be passed through Latin or through Chinese.

Therefore, French loan words in Vietnamese with many readings can be moved through Latin or through Chinese, and in addition, these words are also transliterated into Vietnamese and have Vietnamese spellings. This spelling is far different from the original loanword. Meanwhile, French loan words in English mostly keep their original state or have a slight change in the spelling of the original word, but not as much as in Vietnamese.

The study of French loanwords in English and Vietnamese helps Vietnamese people learn foreign languages better. Besides, it helps Vietnamese learners understand the origin of English words and Vietnamese words. Vietnamese, since then, have had more affection for the mother tongue.

This study initially explores French loanwords in English and Vietnamese. I hope that in the following studies, I can study loan words in Vietnamese, such as borrowed words from English, German, Italian, Japanese... in Vietnamese or research on words. Borrowed in English from which to see the variety and understand the pronunciation and meaning of words in these two languages to help the teachers and students learn and teach foreign languages better.

English has gone through many phases during which a substantial number of terms were borrowed from another language. Not only does it borrow from other languages, but it also borrows from others. The more connections the language has, the more loan terms it will acquire. Borrowing and lending result in the fusion of several languages from 
various countries, resulting in the formation of new English terms. As is true of politics, journalism, and finance, contemporary English has created a collection of scientific and technical terminology that is common to and utilized by all languages. Although several terms from French, German, Russian, Spanish, Japanese, and Arabic have been "imported" into English, the language's widespread use, openness, flexibility, tolerance, and innovation enable it to serve as the primary body of international language when vocabularies are merged.

\section{AUTHORS' CONTRIBUTIONS}

Dr. Phuong, Vo Tu is the only author of this article.

\section{REFERENCES}

[1] A. L. Wenden, Learner strategies for learner autonomy. Englewood Cliffs, NJ: Prentice-Hall, 1991.

[2] A. Mizumoto, Exploring the art of vocabulary learning strategies: A closer look at Japanese EFL university students. Tokyo: Kinseido, 2010.

[3] A. P. Cowie, Oxford dictionary of current idiomatic English. Oxford: Oxford University Press, 1975.

[4] A. Psaltou-Joycey, Language learning strategies in the foreign language classroom. Thessaloniki: University Studio Press, 2010.

[5] B. Harley \& D. Hart, Vocabulary learning in the content-oriented second language classroom: Student perceptions and proficiency. Language Awareness, 9, 78-96. 2000.

[6] B. Laufer, \& J. Hulstijn, Incidental vocabulary acquisition in a second language: The construct of task-induced involvement. Applied Linguistics, 22, 1-26, 2001.

[7] C. A. Fraser, Lexical processing strategy use and vocabulary learning through reading.
Studies in Second Language Acquisition, 21, 225-241, 1999.

[8] C. Griffiths, Language learning strategies: Students' and teachers' perceptions. ELT Journal, 61(2), 91-99, 2007.

[9] D. A. Watkins, \& Biggs, J. B. (Eds.). The Chinese learner: Cultural, psychological and contextual influences. Hong Kong and Melbourne: Comparative Education Research Centre, University of Hong Kong and The Australian Council for Educational Research Ltd, 1996.

[10] D. Crystal, (2003). The Cambridge Encyclopedia of the English Language (2nd ed.). Cambridge University Press, 2003. Retrieved 4 February 2015. Lay summary (4 February 2015)

[11] D. Little, Learner Autonomy 1: Definitions, Issues and Problems. Dublin, Ireland: Authentik, 1991.

[12] E. König, (1994). In König, Ekkehard; van der Auwera, Johan. The Germanic Languages. Routledge Language Family Descriptions. Routledge. pp. 532-562. Retrieved 26 February 2015. (26 February 2015).

[13] F. Hyland, Learning autonomously: Contextualising out-of-class language learning. Language Awareness, 13(3), 180202, 2004.

[14] H. F. Nielsen, The Continental Backgrounds of English and its Insular Development until 1154, Odense University Press, 1998.

[15] G. Schraw, Promoting general metacognitive awareness. Instructional Science, 26(1-2), 113-125, 1989.

[16] H. Wise, The vocabulary of modern French: Origins, structure and function. London: Routledge, 1997.

[17] I. Nation, Learning vocabulary in another language. Cambridge: Cambridge University Press, 2001.

[18] I. S. P. Nation, Beginning to learn foreign vocabulary: A review of the research. RELC Journal, 13, 14-36, 1982. 
[19] J. Algeo,"Chapter 2:Vocabulary". In Romaine, Suzanne. Cambridge History of the English Language. IV: 1776-1997. Cambridge University Press. pp. 57-91, 1999 , doi:10.1017/CHOL9780521264778.003.

[20] J. Ayto, A century of new words. Oxford: Oxford University Press, 2007.

[21] J. Bosworth, \& Toller, T. Northcote (1921). "Engla land". An Anglo-Saxon Dictionary (Online). Charles University. Retrieved 6 March 2015.

[22] J. Read, Vocabulary and testing. In $N$. Schmitt \& M. McCarthy (Eds.), Vocabulary: Description, acquisition and pedagogy, (pp. 303-320). Cambridge: Cambridge University Press, 2002.

[23] J. Speake, The Oxford dictionary of foreign words and phrases. Oxford: Oxford University Press, 1997.

[24] K. Haastrup, Lexical inferencing procedures or talking about words: Receptive procedures in foreign language learning with special reference to English. Tübingen: Gunter Narr, 1991.

[25] K. Parry, Vocabulary and comprehension: Two portraits. In J. Coady \& T. Huckin (Eds.), Second language vocabulary acquisition: A rationale for pedagogy (pp.55-68). Cambridge: Cambridge University Press, 1997.

[26] L. N. Zhou, American neologism and modern American culture. Beijing: China Social Sciences Press, 2015.

[27] L. Tian, A Comparative Study of Loanwords in English and Chinese in the Perspective of Language Contact. MA Dissertation, Central South University, 2007.

[28] M. Marttinen, Vocabulary learning strategies used by upper secondary school students studying English as a second language. A-Pro Gradu Thesis in English, University of Jyväskylä Finkenstaedt, 2008.
[29] M. N. Chừ, V. Đ. Nghiệu, H. T. Phiến (2008), Cơ sở ngôn ngũ họ và tiếng Việt, Nxb Giáo dục, Hà Nội, 2008.

[30] N. Đ. Tồn (2002), Tìm hiểu đặc trung văn hóa dân tộc của ngôn ngũ và tu duy ở người Việt (trong sự so sánh với các dân tộc khác), Nxb Đại học Quốc gia, Hà Nội, 2002.

[31] N. Ellis, Consciousness in second language learning: Psychological perspectives on the role of conscious processes in vocabulary acquisition. AILA Review, 11, 37-56, 1994.

[32] N. Schmitt, Vocabulary learning strategies. In N. Schmitt \& M. McCarthy (Eds.), Vocabulary: Description, acquisition and pedagogy, (pp. 199-227). Cambridge: Cambridge University Press, 1997.

[33] N. T. Giáp, Dẫn luận ngôn ngũ hoc: tù bản ngũu và tù ngoại lai. Nhà xuất bản Giáo dục, H., 1998, trang 129-134, 1998.

[34] O' Malley, J. M., \& Chamot, A. (1990). Learning strategies in second language acquisition. Cambridge: Cambridge University Press, 1990.

[35] P. Durkin, Borrowed Words. Oxford: Oxford University Press, 2014.

[36] P. Y. Gu, \& R. K. Johnson, Vocabulary learning strategies and language learning outcomes. Language learning, 46, 643-697. 1996.

[37] P. Meara, Review of second language vocabulary acquisition: A rationale for pedagogy. Applied Linguistics, 19, 289-292, 1998.

[38] P. Schofield, Using the English Dictionary for Comprehension. TESOL Quarterly, 16,185-194, 1982.

[39] P. T. Tình, Sụ đồng hoá các tù gốc Pháp trong tiếng việt, ĐHNN-ĐHQGHN

[40] T. T. Ái, 2018, "Tù̀ điển tù vay muợn trong tiếng Việt Hiện đại", NXB ĐHQG TPHCM, 1998.

[41] P. Zhang, Study on English Loan Words in Chinese. MA Dissertation, Tianjin 
University of Finance \& Economics, 10-15, 2005.

[42] R. L. Oxford, Language learning strategies. What every teacher should know. Boston: Heinle and Heinle Publishers, 1990.

[43] R. Sanaoui, Adult learners' approaches to learning vocabulary in second languages. The Modern Language Journal, 79, 15-28, 1995.

[44] S. Cotterall, Autonomy and Good Language Learners, In Griffiths C. (ed.), Lessons from Good Language Learners, pp. 83-98. Cambridge, UK: Cambridge University Press, 2008.

[45] T. Finkenstaedt, W. Dieter, Ordered profusion; studies in dictionaries and the English lexicon. C. Winter. ISBN 3-53302253-6, 1973.

[46] T. Zeng (2005). Cong niu jin Ying yu ci dian Jian bian di wu ban kan han yu wen hua te se ci Ying Yi fang Xiang (Translating Chinese Culture-Specific Words into English - from a Perspective of Shorter Oxford English Dictionary 5th edition). Journal of Guangdong University of Foreign Studies. B11, 74-77, 2005.

[47] Y. Q. Jumah, “The history of loan words in English and its impact on the English Lexicon",Journal of Critical Reviews, 2019.

[48] Y. Zou, On Chinese Loanwords in English. Journal of Chongqing Vocational \& Technical Institute, 5, 98-99, 2006. 